\title{
Homenagem ao professor Diego César Terra de Andrade
}

A trajetória acadêmica do Professor Diego Terra teve início em 2000, quando ingressou no Curso de Administração na Universidade Federal de Lavras (UFLA). Durante a graduação, esteve envolvido em atividades de Ensino, Pesquisa e Extensão, além de trabalhar diretamente com a administração pública, na Diretoria de Processos Seletivos da UFLA.

Após a graduação, fez MBA em Hotelaria na Universidade Federal de Juiz de Fora/SENAC e trabalhou no setor hoteleiro durante cinco anos, período este em que teve a oportunidade de exercer funções administrativas e vivenciar diferentes experiências, atuando como trainee em empresa de grande porte, consultor para a implantação de negócios e professor no Curso de Pós-Graduação em Administração Hoteleira, do SENAC Araxá (primeira experiência como docente).

No ano de 2010, já decidido a se dedicar em tempo integral à docência, o Professor Diego cursou disciplinas isoladas no Programa de Pós-Graduação em Administração da UFLA, experiência esta que foi decisiva para refletir e discutir sobre suas inquietações profissionais e problematizar sobre o projeto de pesquisa que, posteriormente, foi submetido ao processo seletivo para o Mestrado Acadêmico em Administração, também na UFLA.

A questão de pesquisa que balizou sua dissertação foi fundamentada em sua vivência nos setores público e privado, em concursos, no processo de gestão de pessoas e em disciplinas cursadas como aluno especial, e tratou da socialização organizacional em uma Instituição Pública, em trabalho intitulado "Socialização organizacional em uma IFES Mineira em tempos de REUNI".

O professor Diego afirma que algumas disciplinas/linhas de pesquisa, tais como "Fundamentos e Medidas da Psicologia", "Psicologia do Trabalho e Organizacional", "Recursos Humanos nas Organizações", "Cultura e Mudança nas Organizações" e "Teoria Organizacional", foram imprescindíveis para determinar sua postura diante das pesquisas acadêmicas, pois possibilitaram a formação de um pensamento científico crítico em Administração e serviram como exercício reflexivo sobre as questões e inquietações, sobretudo no ambiente organizacional do setor público, onde se encontra seu foco de pesquisa atual.

Sua primeira experiência profissional no Instituto Federal de Educação Ciência e Tecnologia do Sul de Minas Gerais (IFSULDEMINAS) foi no Campus Machado, em 2010, exercendo o cargo de Professor Substituto da área de Administração, enquanto ainda cursava o Mestrado. No ano seguinte, foi aprovado em concurso para docente e passou a fazer parte do quadro efetivo e em regime de dedicação exclusiva do Instituto, desta vez no Campus de Pouso Alegre.

Atualmente concilia as atividades do magistério sem se manter afastado dos estudos acadêmicos (doutoramento em curso), participa de diferentes Comissões, Órgãos Colegiados e de representação e exerce o cargo de Diretor de Ensino, Pesquisa e Extensão do Campus Pouso Alegre, desde novembro de 2012. Nesse período, contribuiu com a estruturação e consolidação do Campus, e com a implantação e implementação dos Cursos Superiores de Engenharia Civil e Engenharia Química e dos Cursos Técnicos Integrados.

No campo da pesquisa, é atuante parecerista da revista "Agrogeoambiental" - periódico científico do IFSULDEMINAS, e de outros periódicos e eventos de destaque no país.

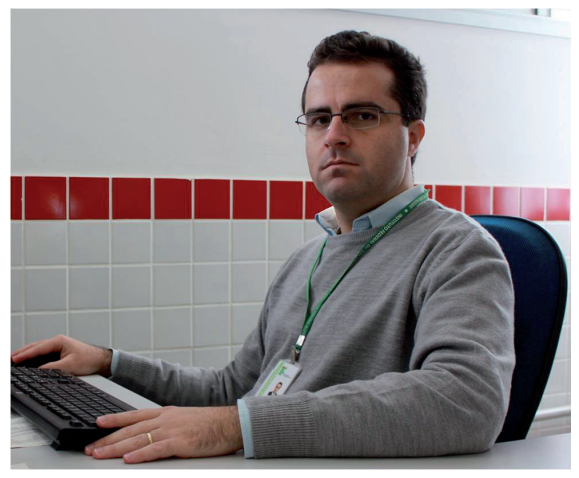

"Almejo para o futuro, continuar contribuindo com a Revista Agrogeoambiental e com outros meios de disseminação do conhecimento cientifico, bem como com o IFSULDEMINAS, nas diferentes instâncias, atividades administrativas e de magistério, de maneira sistêmica e 'tocquevilliana'.

Permanecerei trabalhando para isso!', diz. 


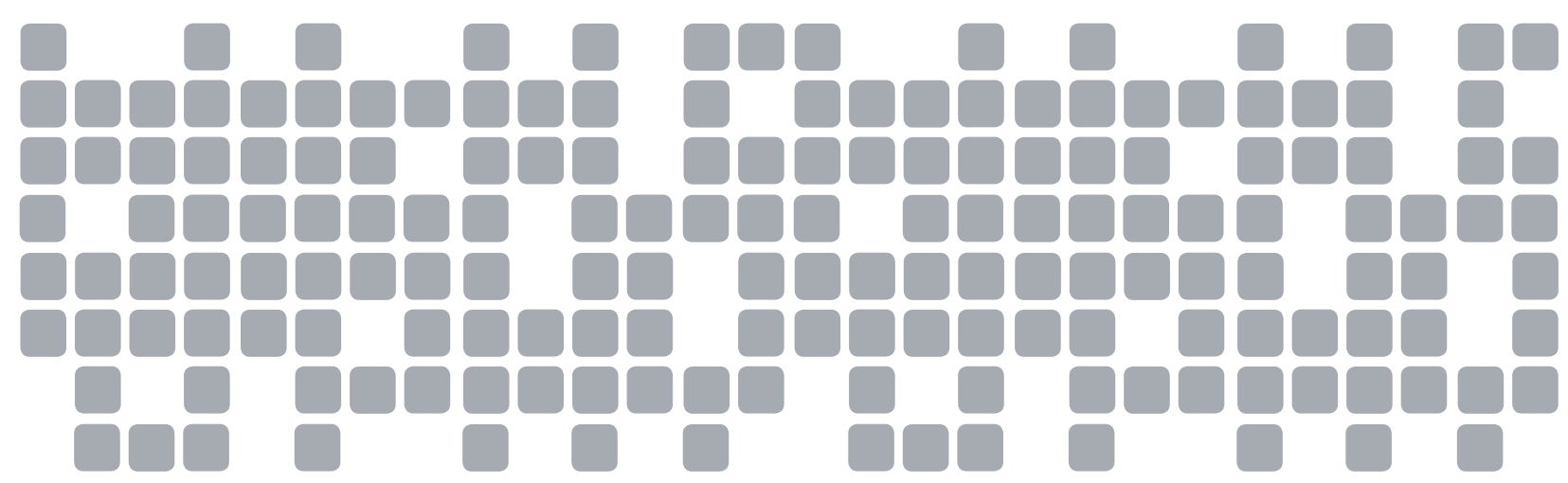

